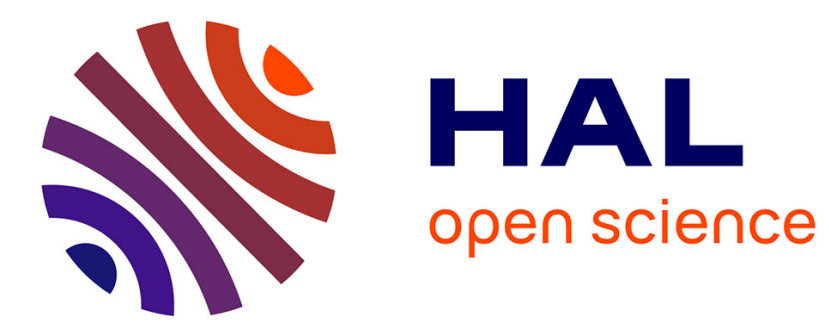

\title{
General practitioners and vaccination of children presenting with a benign infection
}

M. Le Marechal, L. Fressard, Jocelyn Raude, P. Verger, C. Pulcini

\section{To cite this version:}

M. Le Marechal, L. Fressard, Jocelyn Raude, P. Verger, C. Pulcini. General practitioners and vaccination of children presenting with a benign infection. Médecine et Maladies Infectieuses, 2018, 48 (1), pp.44-52. 10.1016/j.medmal.2017.09.018 . hal-01789197

\section{HAL Id: hal-01789197 \\ https://hal.science/hal-01789197}

Submitted on 11 Apr 2019

HAL is a multi-disciplinary open access archive for the deposit and dissemination of scientific research documents, whether they are published or not. The documents may come from teaching and research institutions in France or abroad, or from public or private research centers.
L'archive ouverte pluridisciplinaire HAL, est destinée au dépôt et à la diffusion de documents scientifiques de niveau recherche, publiés ou non, émanant des établissements d'enseignement et de recherche français ou étrangers, des laboratoires publics ou privés. 


\title{
General practitioners and vaccination of children presenting with a benign infection
}

\section{Médecins généralistes et vaccination des enfants présentant une infection fébrile non compliquée}

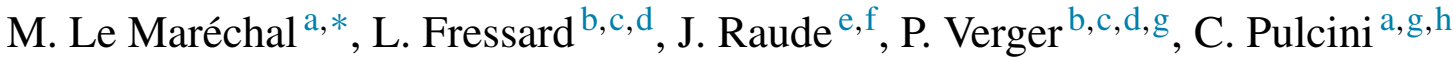 \\ ${ }^{\text {a }}$ Université de Lorraine, EA 4360 APEMAC, 54000 Nancy, France \\ ${ }^{\mathrm{b}}$ Aix-Marseille université, UMR_S912, IRD, 13000 Marseille, France \\ ${ }^{\mathrm{c}}$ Observatoire régional de la santé Provence-Alpes-Côte d'Azur (ORS PACA), 13000 Marseille, France \\ d Inserm, UMR_S912, «Sciences Économiques \& Sociales de la Santé et Traitement de l'Information Médicale » (SESSTIM), 13000 Marseille, France \\ ${ }^{\mathrm{e}}$ EHESP-Rennes, Sorbonne-Paris-Cité, 35043 Rennes, France \\ ${ }^{\mathrm{f}}$ Aix-Marseille université, EPV-UMR_D 190 «Émergence des Pathologies Virales », 13000 Marseille, France \\ ${ }^{\mathrm{g}}$ Inserm, F-CRIN, I-Reivac (Innovative clinical research network in vaccinology), 75654 Paris, France \\ ${ }^{\mathrm{h}}$ Service de maladies infectieuses et tropicales, CHRU de Nancy, 54000 Nancy, France
}

Received 16 December 2016; accepted 28 September 2017

Available online 4 November 2017

\begin{abstract}
Purpose. - To assess the self-reported vaccination behavior of general practitioners (GPs) when asked whether they would recommend the vaccination of a child presenting with a febrile uncomplicated common cold.

Methods. - We performed a cross-sectional survey in 2014 on a national sample of GPs. GPs were randomly assigned to one of eight clinical vignettes, all describing a child presenting with an uncomplicated febrile common cold, but differing by age (4 or 11 months), temperature ( $38{ }^{\circ} \mathrm{C}$ or $39^{\circ} \mathrm{C}$ ), and the mother's emotional state (calm or worried). GPs were asked whether they would recommend immediate vaccination of the child with a hexavalent vaccine (diphtheria, tetanus, pertussis, poliomyelitis, Haemophilus influenzae type b, and hepatitis B), or postpone it. We investigated the relation between the GPs' recommendation to vaccinate, the clinical vignette's variables, and the GPs' perceptions, attitudes, and practices toward vaccination in a multivariate model.

Results. - Among the 1582 participating GPs, $6 \%$ recommended immediate vaccination. This behavior was more frequent with a temperature of $38^{\circ} \mathrm{C}$ rather than $39^{\circ} \mathrm{C}(10 \%$ vs. $3 \%, P<0.001)$. GPs who felt comfortable giving explanations about vaccine safety were more likely to recommend immediate vaccination of the febrile child $(P=0.045)$, but none of the other GPs' characteristics were associated with their vaccination behavior.

Conclusions. - Almost all GPs postponed the hexavalent vaccination of the febrile child presenting with an uncomplicated viral disease; fever being the major factor affecting their decision. More research is needed on vaccination responses in sick children, as well as clearer guidelines.

(C) 2017 Elsevier Masson SAS. All rights reserved.
\end{abstract}

Keywords: Fever; General practitioner; Immunization; Vaccination

\section{Résumé}

Objectifs. - Évaluer le comportement des médecins généralistes (MG) face à une éventuelle vaccination d'un enfant avec une rhinopharyngite fébrile non compliquée.

Méthodes. - Étude transversale sur un échantillon national de MG (2014). Chaque MG a reçu une vignette clinique parmi huit, toutes décrivant un enfant avec une rhinopharyngite fébrile non compliquée. Les vignettes différaient sur l'âge (quatre ou 11 mois), la température $\left(38^{\circ} \mathrm{C}\right.$ ou $\left.39^{\circ} \mathrm{C}\right)$ et le comportement de la mère (calme ou inquiète). Nous avons demandé aux MG s'ils recommanderaient la vaccination

\footnotetext{
* Corresponding author. Faculté de médecine de Nancy, EA-4360 APEMAC, 9, avenue de la Forêt-de-Haye, 54505 Vandœuvre-Lès-Nancy, France.

E-mail address: marionlemarechal@gmail.com (M. Le Maréchal).
} 
de cet enfant le jour même avec le vaccin hexavalent (diphtérie, tétanos, poliomyélite, Haemophilus influenzae de type b, hépatite B, coqueluche) ou s'ils la reporteraient. Avec un modèle multivarié, nous avons analysé la relation entre la recommandation du MG de vacciner ou non et ses perceptions, attitudes et pratiques concernant la vaccination. Résultats

Parmi les 1582 participants, $6 \%$ ont recommandé la vaccination de l'enfant le jour même. Cette décision était plus fréquente quand la température était de $38^{\circ} \mathrm{C}$ plutôt que $39^{\circ} \mathrm{C}(10 \%$ contre $3 \%, p<0,001)$. Les MG qui se sentaient à l'aise pour donner des explications concernant la sécurité des vaccins étaient plus enclins à vacciner l'enfant le jour même $(p=0,045)$.

Conclusions. - Presque tous les MG repousseraient la vaccination d'un enfant présentant une rhinopharyngite fébrile non compliquée ; l'intensité de la température étant le principal facteur influençant leur décision. Davantage de recherches sont nécessaires concernant la réponse vaccinale chez l'enfant malade, ainsi que des recommandations plus claires.

(C) 2017 Elsevier Masson SAS. Tous droits réservés.

Mots clés : Fièvre ; Immunisation ; Médecin généraliste ; Vaccination

\section{Introduction}

Children presenting with fever frequently consult their general practitioner (GP). They account for approximately $20-39 \%$ of pediatric consultations $[1,2]$, and an estimated $67 \%$ of oneyear-old children present more than 60 days of respiratory illness during their first year of life, especially if they are going to day care center [3,4]. It is then common practice for primary care physicians to manage children who need to be vaccinated, but present with a febrile or afebrile benign infection. Available guidelines provide conflicting and sometimes unclear advice on how to deal with such a situation. For instance, the American recommendation of the Advisory Committee on Immunization Practices states that "vaccination should not be delayed because of the presence of mild respiratory tract illness, or other acute illness with or without fever" [5]; in the United Kingdom, the Green book states that "minor illnesses without fever or systemic upset are not valid reasons to postpone immunization. If an individual is acutely unwell, immunization may be postponed until they have fully recovered" [6]; in France the Vaccination Guide states that "Contrary to popular opinion, minor infectious diseases, [...], are not contraindications to vaccination" [7], but fever is not mentioned in the recommendations.

How do physicians deal with these recommendations in daily practice? To the best of our knowledge no study has ever assessed the practices of GPs regarding the vaccination of children presenting with a febrile benign infection.

To better understand the vaccination practices, perceptions, and attitudes of GPs in France, we performed a cross-sectional survey within a large representative sample of French GPs. We focused on the following objectives: to assess the self-reported vaccination behavior of physicians when asked whether they would recommend the vaccination of a child presenting with a febrile uncomplicated common cold and to identify the factors associated with GPs' responses.

\section{Material and methods}

\subsection{Literature and website search}

Recommendations from all countries, available online in French or English language were searched to look for recommendations/guidelines on the vaccination of patients presenting with a benign infection, with or without fever.

\subsection{Sample}

This work took advantage of a recurrent series of national surveys on a representative sample of GPs in private practice designed to study their attitudes, perceptions, and practices related to various medical topics. The method used to set up the survey has been described elsewhere in detail [8]. Enrolment took place between December 2013 and March 2014. Participants were selected by random sampling from the Ministry of Health exhaustive database of healthcare professionals in France (RPPS, Healthcare workers shared repertoire). Sampling was stratified by gender, age (terciles: $<50$ years, [50-57] years, $>57$ years), potential local accessibility to GPs of the municipality of practice (three categories based on the variation around the national average: $<-19.3 \%,[-19.3$ to +17.7$] \%$, or $>+17.7 \%$, and the physicians' workload (number of procedures during the year 2012: $<3,067,[3,067-6,028],>6,028)$. GPs with an exclusive practice of alternative medicine (acupuncture, homeopathy, naturopathic medicine, etc.), or with $<5.2$ visits per week in 2012 were excluded. GPs who agreed to participate in the overarching survey committed themselves to answering the entire series of surveys: one survey every six months for two and a half years, totaling six surveys. To limit any selection bias that might have resulted from specific opinions/attitudes, the topics of each survey were only mentioned to GPs after they were asked to participate. Of the 5,151 randomly selected GPs for the overarching survey, 695 could not be contacted and 732 were not eligible. Of 3,724 eligible GPs, 1,712 agreed to participate (46.0\%) (Fig. 1). GPs who refused to participate were more often men $(P<0.001)$, older $(P<0.001)$, and had more consultations in $2012(P<0.05)$. They reported two main raisons for refusing participation: lack of time $(55 \%)$ and lack of interest in participating in a survey $(31 \%)$.

The first of these five cross-sectional surveys was dedicated to vaccination and was based on a telephone or web-based questionnaire. 


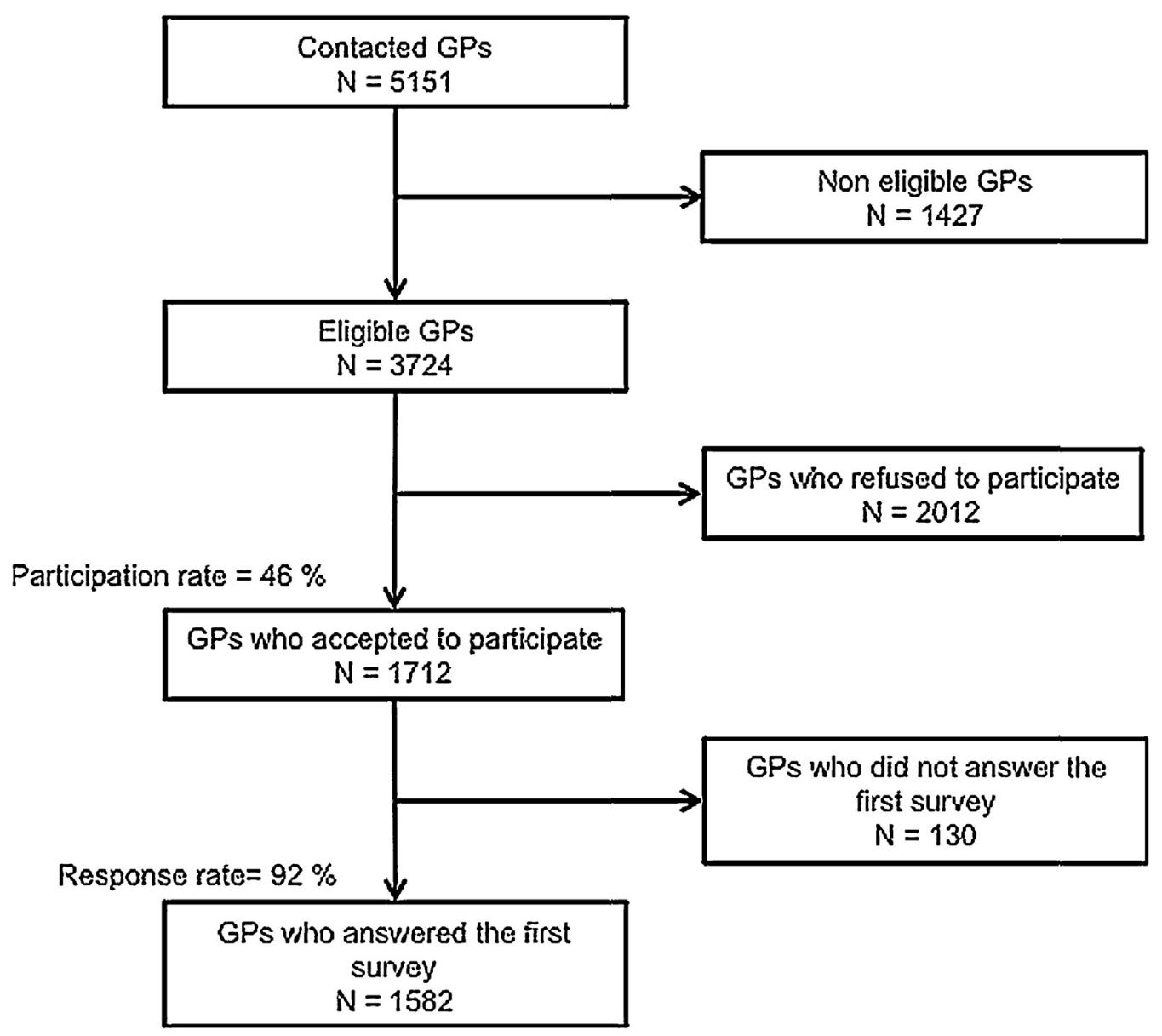

Fig. 1. Flow chart of the general practitioners included in the national French sample. GPs: general practitioners; N: number of GPs. Diagramme des médecins généralistes inclus dans l'échantillon français national.

\subsection{Questionnaire (available from the authors upon request)}

The questionnaire was designed based on a literature review and meetings with experts in the field of vaccination. Information collected focused on:

- general attitudes toward vaccination;

- vaccination practices of GPs for themselves and their family;

- vaccination recommendations of GPs to their patients;

- clinical vignette on fever before vaccination (content explained below);

- beliefs about the potential risks of certain vaccines;

- beliefs about actions that might encourage vaccination.

The questionnaire was tested for clarity and length, and was validated in a pilot study with 50 GPs.

Professional investigators conducted the interviews with computer-assisted telephone interview (CATI) software.

\subsection{Clinical vignette}

A clinical vignette with three variables (each subject to an alternative possibility shown in between brackets) was pre- sented to GPs describing the following situation: "A mother comes to your surgery with her (4 or 11) month-old child for a hexavalent vaccine (diphtheria, tetanus, pertussis, poliomyelitis, Haemophilus influenzae type b, and hepatitis B); the child has been feverish for two days $\left(38\right.$ or $39^{\circ} \mathrm{C}$ ) and present with an uncomplicated common cold; the medical examination is normal; the mother tells you that the child's behavior is the same as usual. The mother is (worried or not worried) about whether her feverish child will be able to cope with the vaccine. GPs were asked the following question: "The mother has brought the vaccine; do you recommend performing the vaccination shot right away, or do you postpone the shot until temperature returns to normal?".

GPs were randomly allocated to one of eight $(2 \times 2 \times 2)$ clinical scenarios, differing by age of the child (4- or 11-month-old), temperature $\left(38\right.$ or $39^{\circ} \mathrm{C}$ ), and the mother's emotional state (calm or worried).

\subsection{Statistical analysis}

The dependent variable was "GP's recommendation to the mother to have her child vaccinated that day" (yes/no).

We assessed three potential explanatory variables related to the clinical vignette: the child's age and temperature, and the 
mother's emotional state. We also assessed GPs' characteristics, including their perceptions, attitudes, and practices toward vaccination:

- GPs' perceptions (two variables): their perceived need for training in vaccination; their perception of being more or less comfortable giving explanations to patients about the safety of vaccines;

- GPs' attitude (one variable): their opinion concerning vaccination in general in their daily practice (more or less favorable);

- GPs' practices (three variables): participation in any continuing medical education over the past 12 months on the topic of infectious diseases and/or vaccination; consultation of the French vaccination guide; and finally whether they had been confronted with a serious health issue, i.e. one which led to hospitalization, disability, etc., potentially linked to a vaccination in one of their patients.

For the descriptive analysis, data were weighted to match the sample more closely to the national French GP population for age, gender, 2012 workload, and potential local accessibility to GPs of the municipality of practice. We then performed bivariate analyses between the dependent variable and the explanatory variables using the chi-squared test or Fisher's exact test. Finally, we performed a multivariate analysis using a log-binomial regression adjusted on the four stratification variables (GP's age, gender, 2012 workload, and potential local accessibility) [9], on GPs' type of practice (solo or group practice), and on the occasional practice of alternative medicine (yes/no). The three variables of the clinical vignette, and all the variables of interest with a $P<0.1$ in the bivariate analyses were entered into the model as explanatory variables. All analyses were based on twosided $P$ values, with statistical significance defined by $P<0.05$. Analyses were performed using the R software (version 3.0.3) and the "survey" package.

\section{Results}

\subsection{Literature and website search}

Recommendations addressing the practice to adopt when a patient (children/adults) presents with a (febrile or afebrile) benign infection are summarized in Table 1. Results are divided into four categories:

- countries recommending vaccination irrespective of the temperature (United States, Switzerland, and Canada) [5,10,11];

- countries defining a temperature cut-off to decide whether or not to vaccinate the child $\left(38^{\circ} \mathrm{C}\right.$ in Ireland and New Zealand, $38.5^{\circ} \mathrm{C}$ in Australia) [12-14];

- countries with somewhat unclear recommendations (United Kingdom, France) [6,7];

- countries with no recommendation found.

\subsection{Cross-sectional nationwide survey}

Of the 1,712 GPs who agreed to participate in the overarching survey, 1,582 GPs (92\%) answered the first cross-sectional survey on vaccination (Fig. 1). Their characteristics did not differ significantly from the GPs who agreed to participate in the overarching survey, but did not actually answer the vaccination survey (130 GPs).

Table 1

Recommendations for the vaccination of a (febrile or afebrile) child/adult presenting with a benign infection in various countries [5-7,10-14].

Recommandations pour la vaccination d'un enfant/adulte présentant une infection non compliquée (fébrile ou non) dans différents pays [5-7,10-14].

\begin{tabular}{|c|c|c|}
\hline Recommended behavior & Country/institution & Quotation \\
\hline $\begin{array}{l}\text { Vaccination, irrespective } \\
\text { of temperature }\end{array}$ & $\begin{array}{l}\text { Switzerland, United } \\
\text { States, Canada }\end{array}$ & $\begin{array}{l}\text { United Sates: "Vaccination should not be delayed because of the presence of mild respiratory tract } \\
\text { illness, or other acute illness with or without fever." } \\
\text { Switzerland: "No contraindication: discreet acute disease, with or without fever." } \\
\text { Canada: "Acute illness (with or without fever). In general, people with minor or moderate acute } \\
\text { illness may receive vaccines. There is no increase in risk of adverse events following immunization } \\
\text { and no interference with response to vaccine." }\end{array}$ \\
\hline $\begin{array}{l}\text { Temperature threshold to } \\
\text { decide whether to } \\
\text { vaccinate }\end{array}$ & $\begin{array}{l}\text { Ireland, New Zealand, } \\
\text { Australia }\end{array}$ & $\begin{array}{l}\text { Cut-off: } \\
\text { Ireland, New Zealand }=38^{\circ} \mathrm{C} \\
\text { Australia }=38.5^{\circ} \mathrm{C}\end{array}$ \\
\hline $\begin{array}{l}\text { Somewhat unclear } \\
\text { recommendations }\end{array}$ & $\begin{array}{l}\text { United Kingdom, ECDC, } \\
\text { France, Denmark }\end{array}$ & $\begin{array}{l}\text { United Kingdom: "Minor illnesses without fever or systemic upset are not valid reasons to postpone } \\
\text { immunization. If an individual is acutely unwell, immunization may be postponed until they have } \\
\text { fully recovered." } \\
\text { France: "Contrary to popular opinion, minor infectious diseases, [...], are not contraindications to } \\
\text { vaccination", but fever is not mentioned in the recommendations. } \\
\text { Denmark: "Children who are ill, such as running a fever, are not normally vaccinated. Nevertheless, } \\
\text { children who have a mild cold can be vaccinated." } \\
\text { ECDC: "Babies and children with minor coughs and colds, or those on antibiotics, can be immunized } \\
\text { safely and effectively. However, if your child has a high temperature, the immunization should be put } \\
\text { off until your child is better." }\end{array}$ \\
\hline
\end{tabular}

No recommendation Belgium, Luxembourg,

The Netherlands, Sweden

ECDC: European Centre for Disease Prevention and Control. 
The weighted descriptive analysis revealed that $6.3 \%$ of GPs reported that they would recommend the immediate vaccination of the febrile child presenting with an uncomplicated common cold. Characteristics of GPs are described in Table 2. As the results of weighted and non-weighted descriptive analyses were similar, only unweighted analyses are presented in the bivariate and multivariate analyses.

Among GPs' characteristics, the two only variables that were significant in bivariate analysis and were added to the multivariate model (Table 3) were: feeling comfortable giving explanations to patients about the safety of vaccines, and consulting the French vaccination guide. The multivariate analysis showed that the intensity of fever was the only factor from the vignette that significantly influenced the vaccination behavior of GPs $(10 \%$ recommended the vaccination when the temperature was $38^{\circ} \mathrm{C}$ vs. Three percent when the temperature was $39^{\circ} \mathrm{C}$ $[P<0.001])$; the child's age did not influence the vaccination recommendation, and neither did the mother's behavior. GPs who felt comfortable giving explanations about vaccine safety were more likely to recommend immediate vaccination of the febrile child $(P=0.045)$. None of the other GPs' characteristics were associated with their vaccination behavior (Table 4).

\section{Discussion}

Almost all French GPs (94\%) recommended postponing the vaccination of a febrile child presenting with an uncomplicated common cold. A high temperature was the only factor from the vignette found to be independently associated with postponing vaccination. GPs who felt comfortable giving explanations about vaccine safety were also more likely to immediately vaccinate the feverish child presenting with a benign infection. No other GPs' characteristics were significantly associated with this vaccination behavior.

In the context of national unclear and difficult-to-access recommendations (the French vaccination guide is not well-known by GPs as it is not part of the official annual vaccination schedule edited by the Ministry of Health, and is quite hard to find on the Internet), almost all French GPs chose to postpone the hexavalent vaccination of a febrile child presenting with an uncomplicated common cold. They probably thought that the risks of immediate vaccination outweighed the risks of postponing the vaccination.

As the hepatitis $B$ vaccine is included in the hexavalent vaccine, this might have contributed to this behavior. Hepatitis B vaccine is quite controversial in France [15], but the vignette specified that the mother came to the surgery with the vaccine, implying that she was in favor of her child being vaccinated. The vast majority of GPs included in this study were also not opposed to this vaccine (63\% of them always or often recommended hepatitis B vaccination to teenagers, $95 \%$ of them were themselves vaccinated against hepatitis B, and $84 \%$ had some or all their children vaccinated against hepatitis B).

Our literature and website search highlighted that available international recommendations are conflicting and sometimes unclear on this topic, probably because of a poor level of evidence. Only the American guidelines, issued by the Advisory
Committee on Immunization Practices (ACIP), provide references to support the recommendation to vaccinate a child presenting with an acute illness with or without fever [5,16-18]. However, the cited studies only deal with measles vaccination, and their scientific quality is insufficient to conclude on the consequences of vaccinating a febrile child. The work of Lindegren et al. determined the proportion of valid contraindication for measles vaccination during a measles outbreak in two different emergency departments. They noticed that children presenting with current fever or a history of fever were less vaccinated (22\%) than children visiting hospital for another reason (48\%; $P<0.05)$. However, no follow-up was performed for children vaccinated during the febrile episode.

On the basis of literature data and common preconceptions in the medical field, the main potential perceived risks of immediate vaccination are:

- the simultaneity of the vaccine administration and the common cold could make it difficult to determine the cause of the fever after vaccination [6];

- lower vaccine effectiveness during a common cold is possible but not demonstrated [19];

- GPs and/or parents might want to avoid worsening the child's condition in the short-term caused by the vaccination (for example the intensity of the fever might lead to more febrile seizures);

- GPs might fear that parents may overestimate the vaccination's side effect (the fever) and therefore might be less inclined to vaccinate their child in the future, and also GPs could think that if they agree to the parents' wish to postpone vaccination, it will allow for a greater degree of trust between them [20]. The last two hypotheses are not supported by any available literature, but are consistent with the result indicating that GPs who felt comfortable providing explanations about vaccine safety were more likely to recommend the immediate vaccination of the febrile child as this implies feeling confident to reassure parents and promote vaccination.

On the other hand, what are the potential risks of postponing vaccination? There is evidence showing that postponing vaccination in childhood may lead to missed opportunities, not just for the individual. It may also weaken collective protection against preventable infectious diseases and it is a risk factor for outbreaks (such as the measles outbreak in Europe in 2008-2011) [21]. It has been estimated that a child who experience at least one missed vaccination opportunity is 3.1 times less likely to be completely immunized than a child who never missed a vaccination opportunity [22]. Low socioeconomic status [23,24], parents' negligence [25], or vaccine hesitancy [25,26] are known risk factors for postponing vaccination. However, to date little is known about the role of minor illnesses, and especially about the influence of fever in these missed opportunities [24]. Postponing a vaccination shot in a feverish child might lead to it never being administered or administered with a long delay [21]. 
Table 2

Descriptive analysis of the study population (French nationwide survey of general practitioners, weighted data, $n=1582$ ).

Analyses descriptives de la population d'étude (enquête nationale auprès de médecins généralistes français, données pondérées, $\mathrm{n}=1$ 582).

\begin{tabular}{|c|c|c|}
\hline & \multicolumn{2}{|c|}{ Survey participants } \\
\hline & $n=1,582$ & Frequency $(\%)$ \\
\hline \multicolumn{3}{|l|}{ Stratification variables } \\
\hline \multicolumn{3}{|l|}{ Gender } \\
\hline Male & 1076 & 68.0 \\
\hline Female & 506 & 32.0 \\
\hline \multicolumn{3}{|l|}{ Age (years) } \\
\hline$<50$ & 538 & 34.0 \\
\hline$[50-58]$ & 556 & 35.1 \\
\hline$>58$ & 488 & 30.9 \\
\hline \multicolumn{3}{|c|}{ Potential local accessibility to GPs of the municipality of practice ${ }^{a}$} \\
\hline$<-19.3 \%$ & 406 & 25.7 \\
\hline$[-19.3$ to +17.7$] \%$ & 797 & 50.3 \\
\hline$>+17.7 \%$ & 379 & 24.0 \\
\hline \multicolumn{3}{|l|}{2012 workload (number of procedures) } \\
\hline$<3,067$ & 350 & 22.1 \\
\hline$[3,067-6,028]$ & 813 & 51.4 \\
\hline$>6,028$ & 419 & 26.5 \\
\hline \multicolumn{3}{|l|}{ Professional characteristics } \\
\hline \multicolumn{3}{|l|}{ Type of practice (11 NA) } \\
\hline Group practice & 909 & 57.9 \\
\hline Solo practice & 662 & 42.1 \\
\hline \multicolumn{3}{|c|}{ Occasional practice of alternative medicine ${ }^{\mathrm{b}}$ ( 9 NA) } \\
\hline Yes & 243 & 15.4 \\
\hline No & 1330 & 84.6 \\
\hline \multicolumn{3}{|l|}{ Clinical vignette (17 NA) } \\
\hline Recommended to give the vaccination & 98 & 6.3 \\
\hline When the child was $38^{\circ} \mathrm{C}$ & $75 / 781$ & 9.6 \\
\hline When the child was $39^{\circ} \mathrm{C}$ & $22 / 784$ & 2.8 \\
\hline When the child was 4 months old & $51 / 762$ & 6.7 \\
\hline When the child was 11 months old & $47 / 803$ & 5.9 \\
\hline When the mother was calm & $56 / 778$ & 7.2 \\
\hline When the mother was worried & $42 / 787$ & 5.3 \\
\hline \multicolumn{3}{|l|}{ Attitudes of GPs } \\
\hline \multicolumn{3}{|l|}{ Opinion on vaccination in general (7 NA) } \\
\hline Very favorable & 1268 & 80.5 \\
\hline Other opinion & 307 & 19.5 \\
\hline \multicolumn{3}{|l|}{ Perceptions of GPs } \\
\hline \multicolumn{3}{|l|}{ Need for training in vaccination (10 NA) } \\
\hline Yes & 337 & 21.4 \\
\hline No & 1235 & 78.6 \\
\hline \multicolumn{3}{|c|}{ Feel comfortable giving explanations about the safety of vaccines (12 NA) } \\
\hline Yes & 1286 & 81.9 \\
\hline No & 284 & 18.1 \\
\hline \multicolumn{3}{|l|}{ Practices of GPs } \\
\hline \multicolumn{3}{|c|}{ Attendance to any continuing medical education courses $(22 \mathrm{NA})^{\mathrm{c}}$} \\
\hline Yes & 683 & 43.8 \\
\hline No & 877 & 56.2 \\
\hline \multicolumn{3}{|l|}{ Consulted the vaccination guide ( $8 \mathrm{NA}$ ) } \\
\hline Yes & 1203 & 76.4 \\
\hline No & 371 & 23.6 \\
\hline \multicolumn{3}{|c|}{ Has been confronted with a serious health issue potentially linked to a vaccination in one of his/her patients ( 8 NA) } \\
\hline Yes & 254 & 16.2 \\
\hline No & 1320 & 83.8 \\
\hline
\end{tabular}

GP: general practitioner; NA: not available, includes the following answers in the questionnaire: "Doesn't know", "Doesn't answer", or answers not available. Percentages do not include the NA values. Of the 1582 GPs who answered the questionnaire, 86 had at least one missing value, which totals 1496 complete cases.

${ }^{\text {a }}$ Variation around the national average.

b Alternative medicine: homeopathy and/or acupuncture.

${ }^{\mathrm{c}}$ Continuous medical education courses on infectious diseases and vaccination in the previous year. 
Table 3

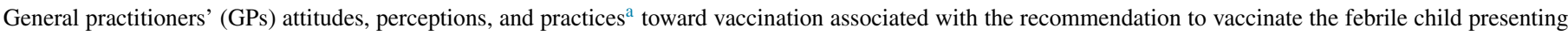
with an uncomplicated common cold (French nationwide survey of GPs, unweighted data, bivariate analysis, $\mathrm{N}=1565$ ).

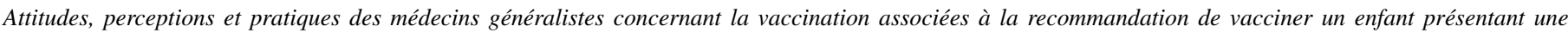

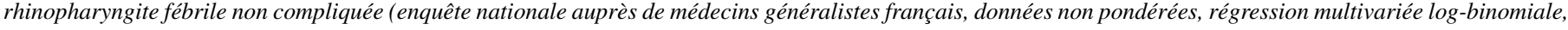
$N=1565)$.

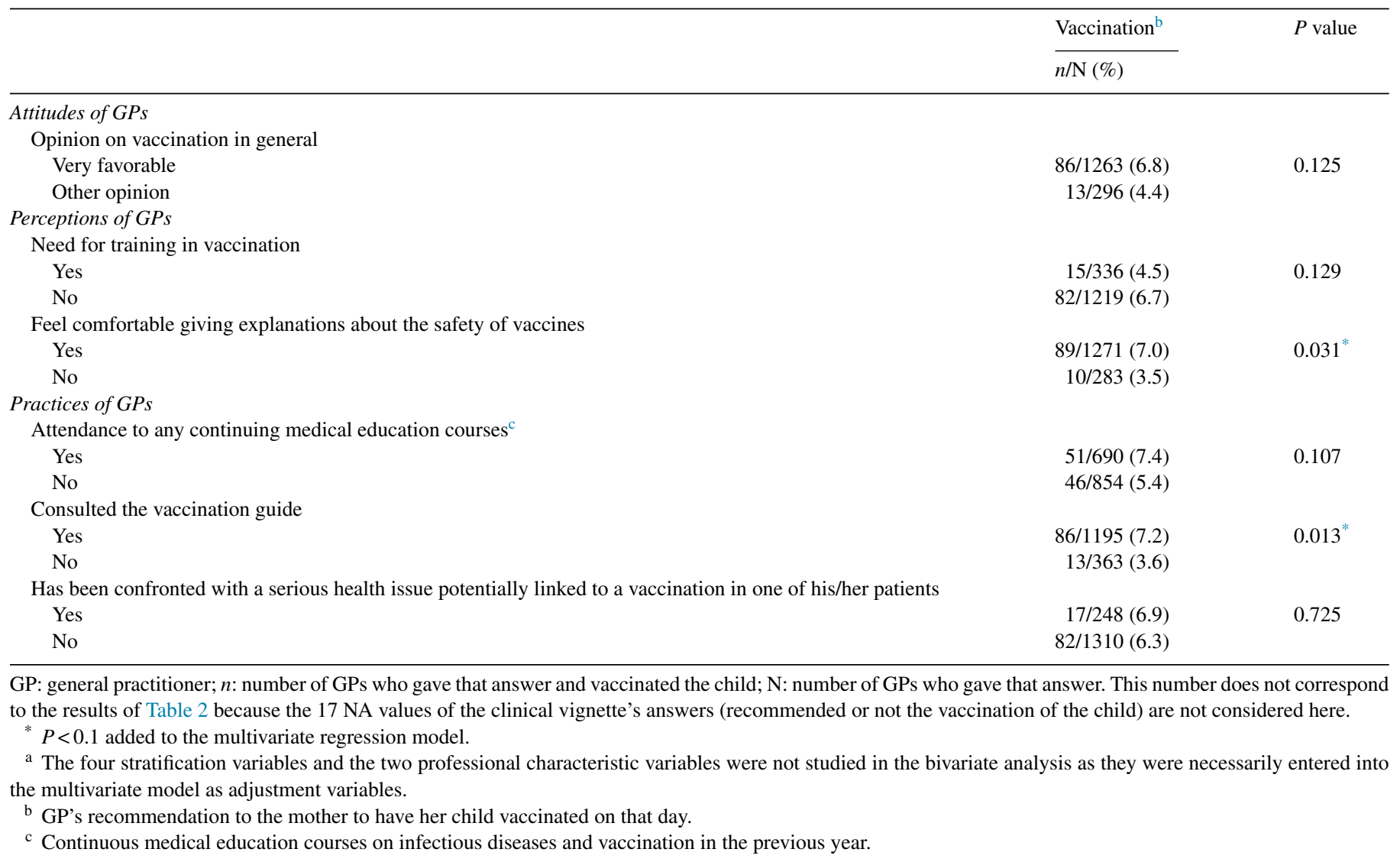

\subsection{Strengths and limitations of the study}

This work is original and is based on a large sample selected in the exhaustive list of French GPs; our study population is therefore very representative. This work also has limitations. Participants may differ from non-participants even though the sample was representative of the French national GP population in terms of gender, age, and 2012 workload. Nevertheless, weighing the data did not affect our results, suggesting that the selection bias was negligible in our study. Moreover, $46 \%$ of eligible GPs agreed to participate in the survey. This is a high response rate compared with other surveys, considering that GPs committed themselves for two and a half years (five different surveys) [27]. Furthermore, the recommendation to vaccinate was not based on real practices. It was based on self-reported behavior, but clinical vignettes have been shown to be a reliable way to assess clinical practice [28-31]. Then, the specificities of the French vaccination system might limit the generalizability of our results. We also did not explore if the surveyed GPs postponing vaccination would have scheduled an appointment for catch-up vaccination, which would have told us if it was a permanent missed opportunity or only a one-time delay vaccination. Finally, the cross-sectional nature of the study did not allow for any causal inferences. Despite these limitations, the decision to postpone the vaccination of a febrile child presenting with an uncomplicated common cold was so frequent in our study that it is unlikely for this conclusion to be biased.

\section{Conclusion}

In this survey conducted among a large representative sample of French GPs, we observed a very high prevalence (94\%) of postponed hexavalent vaccination due to a febrile minor illness. More research is needed to confirm and understand these findings, and to assess the relative risks of immediate and postponed vaccination in this common clinical situation. Clearer and more consistent guidelines would certainly be of help.

\section{Ethical approval}

The National Authority for Statistical information (Conseil national de l'Information Statistique) approved the panel.

\section{Role of the funding source}

MLM was awarded the 2014 grant from the "Vaccination and Prevention" group of the French Infectious Diseases Society (French acronym SPILF). 
Table 4

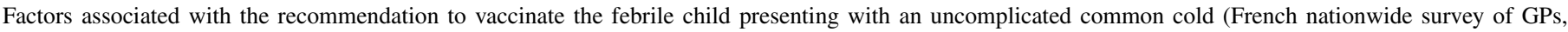
unweighted data, multivariate log-binomial regression, $\mathrm{N}=1565$ ).

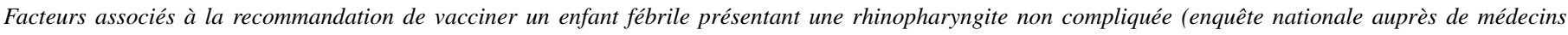
généralistes français, données non pondérées, régression multivariée log-binomiale, $N=1565$ ).

\begin{tabular}{|c|c|c|}
\hline & \multicolumn{2}{|c|}{ Multivariate analysis $^{\mathrm{a}}$} \\
\hline & $P$ value & $\mathrm{RR}[95 \% \mathrm{CI}]$ \\
\hline \multicolumn{3}{|l|}{ Stratification variables } \\
\hline \multicolumn{3}{|l|}{ Gender } \\
\hline Male & 0.252 & $1.29[0.84-1.98]$ \\
\hline Female & & Reference \\
\hline \multicolumn{3}{|l|}{ Age (years) } \\
\hline$<50$ & & Reference \\
\hline$[50-58]$ & 0.734 & $1.08[0.70-1.66]$ \\
\hline$>58$ & 0.574 & $0.86[0.51-1.45]$ \\
\hline \multicolumn{3}{|c|}{ Potential local accessibility to GPs of themunicipality of practice ${ }^{b}$} \\
\hline$<-19.3$ & & Reference \\
\hline$[-19.3$ to +17.7$] \%$ & 0.092 & $1.55[0.93-2.57]$ \\
\hline$>+17.7 \%$ & 0.121 & $1.58[0.89-2.81]$ \\
\hline \multicolumn{3}{|c|}{2012 workload (number of procedures) } \\
\hline$<3,067$ & & Reference \\
\hline$[3,067-6,028]$ & 0.104 & $1.65[0.90-3.04]$ \\
\hline$>6,028$ & 0.629 & $1.19[0.60-2.36]$ \\
\hline \multicolumn{3}{|l|}{ Professional characteristics } \\
\hline \multicolumn{3}{|l|}{ Type of practice } \\
\hline Group practice & 0.117 & $1.41[0.92-2.17]$ \\
\hline Solo practice & & Reference \\
\hline \multicolumn{3}{|c|}{ Occasional practice of alternative medicine ${ }^{c}$} \\
\hline Yes & 0.137 & $0.56[0.26-1.20]$ \\
\hline No & & Reference \\
\hline \multicolumn{3}{|l|}{ Clinical vignette answer } \\
\hline \multicolumn{3}{|l|}{ Fever } \\
\hline $38^{\circ} \mathrm{C}$ & $<0.001^{*}$ & $3.24[2.05-5.13]$ \\
\hline $39^{\circ} \mathrm{C}$ & & Reference \\
\hline \multicolumn{3}{|l|}{ Age (months) } \\
\hline 4 & 0.505 & $1.14[0.78-1.65]$ \\
\hline 11 & & Reference \\
\hline \multicolumn{3}{|l|}{ Mother } \\
\hline Calm & 0.157 & $1.32[0.90-1.92]$ \\
\hline Worried & & Reference \\
\hline \multicolumn{3}{|l|}{ Perceptions of GPs } \\
\hline \multicolumn{3}{|c|}{ Feeling comfortable giving explanations about the safety of vaccines } \\
\hline Yes & $0.045^{*}$ & $1.99[1.01-3.90]$ \\
\hline No & & Reference \\
\hline \multicolumn{3}{|l|}{ Practices of GPs } \\
\hline \multicolumn{3}{|c|}{ Consulted the vaccination guide } \\
\hline Yes & 0.052 & $1.75[1.00-3.09]$ \\
\hline No & & Reference \\
\hline
\end{tabular}

CI: confidence interval; GP: general practitioner.

* $P$ value $<0.05$ considered statistically significant.

a Modelling of the GP's recommendation to the mother to have her child vaccinated on that day.

b Variation around the national average.

c Alternative medicine: for example, homeopathy and/or acupuncture.

PV was awarded a grant from the French Institute for Public Health Research (French acronym IReSP).

The study was funded by the Directorate for Research, Studies, Assessment and Statistics of Ministry of Health (French acronym DREES), the French Ministry of Social Affairs and Health, the National Institute for prevention and health education (French acronym INPES), the National Institute for Health and Medical Research (French acronym Inserm), and the IReSP.

The DRESS and INPES, funding agencies of the study, played a supporting role in the study design and result analysis; the ORS PACA-UMR-SESSTIM ensured scientific coordination of the study.

\section{Contributors}

MLM analyzed and interpreted the data, drafted the article, and approved the final version to be submitted.

LF analyzed and interpreted the data, revised the article for important intellectual content, and approved the final version to be submitted. 
JR contributed to the conception and design of the study, the acquisition of data, revised the article for important intellectual content, and approved the final version to be submitted.

PV supervised the conception and design of the study, the acquisition of data, revised the article for important intellectual content, and approved the final version to be submitted.

CP contributed to the conception and design of the study, the acquisition of data, drafted the article, revised the article for important intellectual content, and approved the final version to be submitted.

\section{Disclosure of interest}

The authors declare that they have no competing interest.

\section{Acknowledgments}

We would like to thank Laura Saez for her careful and attentive help in editing the article.

\section{References}

[1] Hay AD, Heron J, Ness A, ALSPAC study team. The prevalence of symptoms and consultations in pre-school children in the Avon Longitudinal Study of Parents and Children (ALSPAC): a prospective cohort study. Fam Pract 2005;22(4):367-74.

[2] Holme CO. Incidence and prevalence of non-specific symptoms and behavioural changes in infants under the age of two years. Br J Gen Pract 1995;45(391):65-9.

[3] Wald ER, Guerra N, Byers C. Frequency and severity of infections in day care: three-year follow-up. J Pediatr 1991;118(4 Pt 1): $509-14$.

[4] Sannino N. Pathologies infectieuses et mode de garde des enfants d'âge préscolaire synthèse bibliographique. Allocations familiales 2002; 2002 [https://www.caf.fr/sites/default/files/cnaf/dossier_32_-_pathologies_et_ modes_garde_enfant.pdf. Accessed August 8, 2016].

[5] Centers for disease control prevention (CDC). General recommendations on immunization: recommendations of the Advisory Committee on Immunization Practices 2011 (ACIP); 2011 [http://www.cdc.gov/ mmwr/preview/mmwrhtml/rr6002a1.htm. Accessed August 8, 2016].

[6] Public Health England. The green book 2013; 2013 [https://www.gov. uk/government/collections/immunisation-against-infectious-disease-thegreen-book\#the-green-book. Accessed August 8, 2016].

[7] Institut national de prévention et d'éducation pour la santé (INPES). Guide des vaccinations 2012; 2016 [http://www.inpes.sante.fr/10000/ themes/vaccination/guide-vaccination-2012/pdf/GuideVaccinations2012 Vaccinations_pour_les_personnels_de_sante.pdf. Accessed August 8].

[8] Le Maréchal M, Collange F, Fressard L, Peretti-Watel P, Sebbah R, Mikol $F$, et al. Design of a national and regional survey among French general practitioners and methodology of the first cross-sectional survey dedicated to vaccination. Med Mal Infect 2015;45(10):403-10.

[9] Fekedulegn D, Andrew M, Violanti J, Hartley T, Charles L, Burchfiel C. Comparison of statistical approaches to evaluate factors associated with metabolic syndrome. J Clin Hypertens (Greenwich) 2010;12(5):365-73.

[10] Office Fédéral de la santé publique. Les vaccinations : recommandations générales; 2003 [http://www.bag.admin.ch/themen/medizin/ 00682/00684/02535/index.html?lang=fr. Accessed August 8, 2016].

[11] Public Health Agency of Canada. Canadian immunization guide; 2013 [http://www.phac-aspc.gc.ca/publicat/cig-gci/. Accessed August 8, 2016].
[12] National Immunisation Advisory Committee. The immunisation guidelines for Ireland; 2013 [http://www.hse.ie/eng/health/immunisation/ hcpinfo/guidelines/. Accessed August 8, 2016].

[13] Ministry of Health. Immunization handbook 2014. Wellington: Ministry of Health; 2014 [http://www.health.govt.nz/publication/ immunisation-handbook-2014. Accessed August 8, 2016].

[14] Australian Government Department of Health. The Australian immunisation handbook; 2013 [Accessed August 8, 2016, http://www.immunise. health.gov.au/internet/immunise/publishing.nsf/Content/handbook102-1].

[15] Sicard D. Vaccination against hepatitis B or chasing shadows. Rev Med Interne 1999;20(2):119-20.

[16] Halsey NA, Boulos R, Mode F, Andre J, Bowman L, Yaeger RG, et al. Response to measles vaccine in Haitian infants 6 to 12 months old. Influence of maternal antibodies, malnutrition, and concurrent illnesses. N Engl J Med 1985:313(9):544-9.

[17] Ndikuyeze A, Munoz A, Stewart J, Modlin J, Heymann D, Herrmann KL, et al. Immunogenicity and safety of measles vaccine in III african children. Int J Epidemiol 1988;17(2):448-55.

[18] Lindegren ML, Atkinson WL, Farizo KM, Stehr-Green PA. Measles vaccination in pediatric emergency departments during a measles outbreak. JAMA 1993;270(18):2185-9.

[19] Krober MS, Stracener CE, Bass JW. Decreased measles antibody response after measles-mumps-rubella vaccine in infants with colds. JAMA 1991;265(16):2095-6.

[20] Kempe A, O’Leary ST, Kennedy A, Crane LA, Allison MA, Beaty BL, et al. Physician response to parental requests to spread out the recommended vaccine schedule. Pediatrics 2015;135(4):666-77.

[21] Szilagyi PG, Rodewald LE, Humiston SG, Raubertas RF, Cove LA, Doane $\mathrm{CB}$, et al. Missed opportunities for childhood vaccinations in office practices and the effect on vaccination status. Pediatrics 1993;91(1):1-7.

[22] Turner N, Grant C, Goodyear-Smith F, Petousis-Harris H. Seize the moments: missed opportunities to immunize at the family practice level. Fam Pract 2009;26(4):275-8.

[23] Bouhamam N, Laporte R, Boutin A, Uters M, Bremond V, Noel G, et al. Précarité, couverture sociale et couverture vaccinale: enquête chez les enfants consultant aux urgences pédiatriques. Arch Pediatr 2012;19(3):242-7.

[24] Milteer RM, Jonna S. Parental reasons for delayed immunizations in children hospitalized in a Washington, DC, public hospital. J Natl Med Assoc 1996;88(7):433.

[25] Torun SD, Demir F, Hidiroglu S, Kalaca S. Measles vaccination coverage and reasons for non-vaccination. Public Health 2008;122(2):192-4.

[26] Luthy KE, Beckstrand RL, Peterson NE. Parental hesitation as a factor in delayed childhood immunization. J Pediatr Health Care 2009;23(6):388-93.

[27] Joyce CM, Scott A, Jeon S-H, Humphreys J, Kalb G, Witt J, et al. The "medicine in Australia: balancing employment and life (MABEL)" longitudinal survey-protocol and baseline data for a prospective cohort study of Australian doctors' workforce participation. BMC Health Serv Res 2010;10:50.

[28] Michel-Lepage A, Ventelou B, Nebout A, Verger P, Pulcini C. Crosssectional survey: risk-averse French GPs use more rapid-antigen diagnostic tests in tonsillitis in children. BMJ Open 2013;3(10):e003540.

[29] Michel-Lepage A, Ventelou B, Verger P, Pulcini C. Factors associated with the use of rapid antigen diagnostic tests in children presenting with acute pharyngitis among French general practitioners. Eur J Clin Microbiol Infect Dis 2014;33(5):723-8

[30] Pulcini C, Pauvif L, Paraponaris A, Verger P, Ventelou B. Perceptions and attitudes of French general practitioners towards rapid antigen diagnostic tests in acute pharyngitis using a randomized case vignette study. J Antimicrob Chemother 2012;67(6):1540-6.

[31] Veloski J, Tai S, Evans AS, Nash DB. Clinical vignette-based surveys: a tool for assessing physician practice variation. Am J Med Qual 2005;20(3):151-7. 